\title{
POSOUZENÍ PŘESNOSTI FOTOGRAMMETRICKÝCH VÝSLEDKŮ Z NÍZKONÁKLADOVÉ A PROFESIONÁLNÍ KAMERY
}

\author{
ACCURACY ASSESSMENT OF PHOTOGRAMMETRIC RESULTS FROM \\ LOW COST AND PROFESSIONAL CAMERA
}

\author{
Jaromír Prokop ${ }^{*}, 1, J_{a k u b}$ Nosek $^{1}$, Petr Kalvoda ${ }^{1}$, Milan Veselý $^{1}$
}

*205141@vutbr.cz

${ }^{1}$ Vysoké učení technické v Brně, Fakulta stavební, Ústav geodézie, Veveř́ 331/95, Brno

\begin{abstract}
Abstrakt
Cílem článku bylo posoudit přesnost fotogrammetrických výsledků pomocí snímků nízkonákladové kamery, mobilního telefonu Xiaomi Mi 10T Pro a profesionální digitální zrcadlové kamery Canon EOS 6D Mark II. Pro analýzu byla vybrána kaple. Na kapli vytvořeno celkem 51 vlícovacích a kontrolních bodů a byla naskenována i pozemním laserovým skenerem. Blokové vyrovnání paprskových svazků a tvorba mesh modelů proběhla v programu Bentley ContextCapture. Statisticky byly testovány směrodatné $2 \mathrm{D}$ polohové odchylky a směrodatné výškové odchylky na kontrolních bodech a odchylky vůči referenčnímu mračnu bodů z terestrického laserového skenování. Z výsledků vyplývá, že při vhodně zvolené konfiguraci snímkování lze dosáhnout kvalitních fotogrammetrických výsledků i s využitím nízkonákladových kamer.
\end{abstract}

\section{Klíčová slova}

Blízká fotogrammetrie, nízkonákladové kamery, mobilní telefon

\begin{abstract}
The aim of the article was to assess the accuracy of photogrammetric results using images of a low-cost camera, a Xiaomi Mi 10T Pro mobile phone, and a Canon EOS 6D Mark II professional digital reflex camera. A total of 51 control and checkpoints were created at the chapel, and it was scanned by a terrestrial laser scanner. Bundle block adjustment and mesh model generation were performed using Bentley ContextCapture. 2D standard deviations and standard deviations of elevation at checkpoints and deviations from the reference terrestrial laser scanning point cloud were statistically tested. The results show that with a suitably selected imaging configuration, high-quality photogrammetric results can be achieved even with a low-cost camera.
\end{abstract}

\section{Key words}

Close-range photogrammetry, low-cost cameras, mobile phone

\section{1 ÚVOD}

Nízkonákladové kamery představují zajímavý nástroj pro aplikace blízké fotogrammetrie, např́iklad pro tvorbu 3D mesh modelů a mračen bodů budov. Jejich cenová dostupnost a snadná manipulace s nimi z nich činí efektivní prostředek pro sběr dat použitelných pro rekonstrukce prostorových parametrů objektů. V posledních letech došlo v oblasti mobilních telefonů k výrazným navýšením rozlišení fotoaparátů. Výrobci telefonů zvýšili rozlišení kamer i na $108 \mathrm{Mpx}$.

Přesnost výsledných bodových mračen ze snímkování mobilními telefony může být až na úrovni milimetrů [1]. Jako hlavní faktory ovlivňující přesnost autoři uvádějí rozlišení kamery, velikost pixelu a použití adekvátního zpracovatelského softwaru. Testování přesnosti proběhlo na testovacím poli se známými souřadnicemi s pěti mobilními telefony a jednou zrcadlovou kamerou. Nejlepší výsledky na testovacím poli dosáhl mobilní telefon Samsung Galaxy S4 (rozlišení $13 \mathrm{Mpx}$ ) a následně s ním byl nasnímkován i historický objekt.

Vědecké články vznikající na téma využití nízkonákladových kamer mobilních telefonů v aplikacích blízké fotogrammetrie testují mobilní telefony na testovacích polích [2] a objevují se v nich mobilní telefony s nízkým 
rozlišením kamer [3]. Proto je tento článek zaměřen na využití mobilního telefonu, který má již výrazně vyšší rozlišení.

Cílem článku bylo posoudit a porovnat přesnost fotogrammetrických výsledků pomocí snímků z nízkonákladové kamery mobilního telefonu s vysokým rozlišením a profesionálního digitálního zrcadlového fotoaparátu. Přesnost 3D mesh modelů vytvořených ze snímků z obou kamer byla vypočtena na základě odchylek na souboru kontrolních bodů a dále pomocí odchylek mesh modelů vůči referenčnímu mračnu z terestrického laserového skenování. Porovnání přesnosti mesh modelů z obou kamer bylo realizováno pomocí testu shody (Ftest) směrodatných polohových odchylek (2D, 3D) a směrodatných výškových odchylek.

\section{SLEDOVANÝ OBJEKT A POUŽITÉ VYBAVENÍ}

Pro snímkování byla zvolena kaple Panny Marie Pomocnice v Brně-Líšni. Objekt má v půdorysu rozměry 11 a 7 metrů. Úroveň hřbetu střechy je ve výšce 11 metrů a věže 17 metrů nad okolním terénem. Kolem objektu je dostatečný prostor pro snímkování ze všech stran. Textura střechy, věže a spodní části kaple je pro fotogrammetrické zpracování vyhovující. Stěny kaple pokrývá jemnozrnná omítka bez výrazné textury.

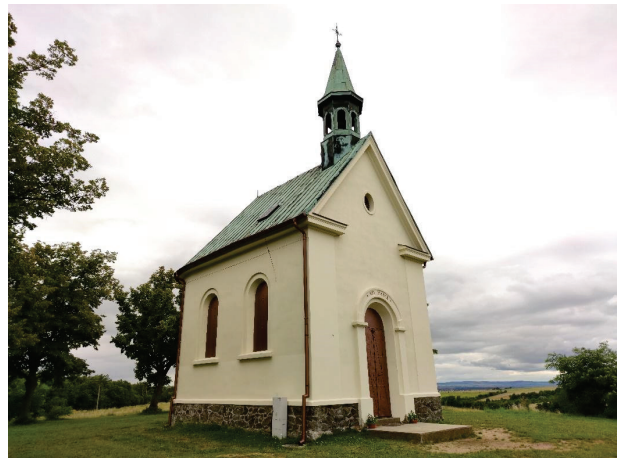

Obr. 1 Kaple Panny Marie Pomocnice v Brně-Líšni.

Pro pořízení snímků kaple a následné porovnání výsledků byly použity dvě kamery. První z nich byla digitální zrcadlová kamera Canon EOS 6D Mark II s 24mm objektivem s pevným ohniskem. Druhou kamerou byl hlavní zadní snímač s optickou stabilizací mobilního telefonu Xiaomi Mi 10T Pro. Referenční mračno kaple bylo vytvořeno pomocí pozemního skeneru Faro Focus 3D X130 a vlícovací a kontrolní body zaměřeny pomocí totální stanice Trimble S8 HP. Vybrané parametry použitých kamer, laserového skeneru a totální stanice jsou uvedeny v Tab. 1 a v Tab. 2.

Tab. 1 Parametry použitých kamer [4], [5], [6].

\begin{tabular}{ccc}
\hline Parametr & Xiaomi Mi 10T Pro & Canon EOS 6D Mark II \\
\hline Typ zařízení & Mobilní telefon & Digitální zrcadlová \\
Rozamera \\
Rozlišenení fototoaparátu & $12032 \times 9024 \mathrm{px}$ & $6240 \mathrm{x} 4160 \mathrm{px}$ \\
Velikost pixelu & $108 \mathrm{Mpx}$ & $26,2 \mathrm{Mpx}$ \\
Clona & $0,8 \mu \mathrm{m}$ & $5,75 \mu \mathrm{m}$ \\
Ekvivalentní ohnisková vzdálenost & 1,7 & 1,4 \\
Pořizovací cena & $26 \mathrm{~mm}$ & $24 \mathrm{~mm}$ \\
Hmotnost & $14990 \mathrm{Kč}$ & $33990 \mathrm{Kč}+44190 \mathrm{Kč}$ \\
\hline
\end{tabular}

Tab. 2 Parametry použitého skeneru a totální stanice [7], [8].

\begin{tabular}{ccc}
\hline Zařízení & Parametr & Hodnota parametru \\
\hline Faro Focus 3D X130 & Typ zařízení & Laser skener \\
& Přesnost měření délek & $2 \mathrm{~mm}$ \\
& Maximální rychlost skenování & $976000 \mathrm{bodů} / \mathrm{s}$ \\
& Dosah měření & $0,6-130 \mathrm{~m}$ \\
\hline
\end{tabular}


Trimble S8 HP

\section{Pořizovací cena}

Hmotnost

Typ zařízení

Přesnost směru měřeného ve dvou

polohách dalekohledu

Přesnost měření délek (na odrazný hranol)

Přesnost měření délek (bezhranolový režim)

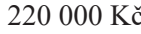

$5,2 \mathrm{~kg}$

Totální stanice

0,3 mgon

$1 \mathrm{~mm}+1 \mathrm{ppm}$

$3 \mathrm{~mm}+2 \mathrm{ppm}$

\section{METODIKA}

Kolem objektu byly stabilizovány celkem 4 body měřické sítě. Předběžné souřadnice těchto bodů byly získány metodou GNSS RTK aparaturou Trimble R8s. Terestrické měření bylo provedeno pomocí totální stanice Trimble S8 HP. Sít' byla polohově vyrovnána jako volná a výškově byla připojena na nivelační bod JM-071-732. Na objektu bylo polární metodou zaměřeno celkem 51 přirozeně signalizovaných vlícovacích a kontrolních bodů. Odhad směrodatné 3D polohové odchylky vlícovacích a kontrolních bodů je $3 \mathrm{~mm}$.

Po zaměření souboru vlícovacích a kontrolních bodů byly na body sítě umístěny vlícovací koule o průměru $20 \mathrm{~cm}$ a celá kaple byla naskenována statickým pozemním skenerem Faro Focus 3D X130. Po registraci mračen z jednotlivých postavení skeneru bylo celé mračno transformováno na čtyři vlícovací koule. Odhad směrodatné 2D polohové odchylky transformovaného referenčního mračna bodů na základě výsledků registrace a georeferencování mračna je 3,3 mm a směrodatná výšková odchylka je 2,4 mm.

Mobilním telefonem Xiaomi Mi 10T Pro bylo pořízeno celkem 52 fotografií z postaveních kolem celého objektu z průměrné vzdálenosti 12 metrů. Foceno bylo v režimu automatického zaostřování na bod. Digitální zrcadlovou kamerou Canon EOS 6D Mark II bylo pořízeno celkem 63 fotografií z postaveních kolem celého objektu z průměrné vzdálenosti 12 metrů.

\section{Zpracování dat z kamer}

Zpracování snímků z kamer proběhlo v programu Bentley ContextCapture. Ve snímcích byly manuálně identifikovány vlícovací a kontrolní body. U zrcadlové kamery byly použity pouze automaticky nalezené navazovací body. U mobilního telefonu bylo nad rámec automatického vyhledání manuálně identifikováno dalších 53 navazovacích bodů.

Prvky vnitřní orientace digitální kamery Canon EOS 6D Mark II byly během výpočtu fixovány na hodnoty získané z předchozí kalibrace (viz Tab. 3). U mobilního telefonu Xiaomi Mi 10T Pro byly tyto prvky vypočteny jedinečně pro každý snímek. Parametry a výsledky blokových vyrovnání paprskových svazků je uvedeno v Tab. 4.

Tab. 3 Prvky vnitřní orientace digitální zrcadlové kamery.

\begin{tabular}{cc}
\hline Prvek & Hodnota \\
\hline Ohnisková vzdálenost & $24,5354 \mathrm{~mm}$ \\
Souřadnice X hlavního bodu & $3073,12 \mathrm{px}$ \\
Souřadnice Y hlavního bodu & $2040,75 \mathrm{px}$ \\
K1 & $-0,0979791$ \\
K2 & 0,0951397 \\
K3 & $-0,026985$ \\
P1 & $-0,0000960807$ \\
P2 & $-0,000874268$ \\
\hline
\end{tabular}

Tab. 4 Parametry a výsledky blokových vyrovnání paprskových svazků.

\begin{tabular}{ccc}
\hline Parametr & Xiaomi Mi 10T Pro & Canon EOS 6D Mark II \\
\hline Počet snímků & 52 & 63 \\
Počet automaticky generovaných navazovacích bodů & 2717 & 8422 \\
Medián počtu navazovacích bodů na snímek & 212 & 628 \\
Medián velikosti pixelu ve skutečnosti & $1,5 \mathrm{~mm}$ & $3,1 \mathrm{~mm}$ \\
Reprojekční chyba navazovacích bodů & $1,0 \mathrm{px}$ & $0,6 \mathrm{px}$ \\
Počet kontrolních bodů & 28 & 23 \\
Reprojekční chyba kontrolních bodů & $4,2 \mathrm{px}$ & $1,3 \mathrm{px}$
\end{tabular}


Po blokovém vyrovnáních paprskových svazků u obou kamer byly vytvořeny $3 \mathrm{D}$ mesh modely kaple. Při vizuální kontrole výsledků v prohlížecím 3D okně byly identifikovány deformace a díry (viz Obr. 2) na stěnách kaple s nedostatečnou texturou jemnozrnné omítky pro fotogrammetrické vyhodnocení.

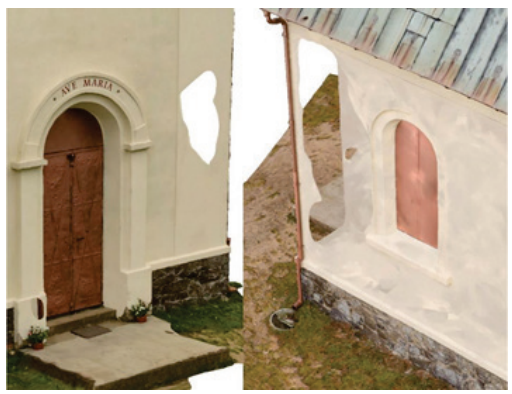

Obr. 2 Deformace v mesh modelech (vlevo Xiaomi, vpravo Canon).

$\mathrm{K}$ vyřešení tohoto problému byly přidány dodatečné geometrické podmínky v problémových oblastech pro zlepšení výsledků 3D rekonstrukce. Tyto podmínky se dají definovat formou 3D polygonů, a to ve formátech .DGN nebo.KML. Zmíněné polygony byly vytvořeny na základě mračna bodů získaného laserovým skenováním.

Přesnost výsledných 3D mesh modelů byla posuzována dvěma různými způsoby. Nejprve byla přesnost v podobě směrodatných $2 \mathrm{D}$ polohových odchylek $\mathrm{S}_{2 \mathrm{D}}$ a směrodatných výškových odchylek $\mathrm{S}_{\mathrm{H}}$ vypočtena na základě rozdílů mezi souřadnicemi kontrolních bodů a souřadnicemi kontrolních bodů manuálně identifikovaných v 3D mesh modelech. Polohové a výškové odchylky na kontrolních bodech byly podle [9] testovány na výskyt vybočujících (5\% kritická hodnota) a odlehlých (1\% kritická hodnota) hodnot.

Dále byla v programu CloudCompare v2.11 provedena analýza odchylek výsledných 3D mesh modelů od referenčního mračna bodů z pozemního laserového skenování. Odchylky od referenčního mračna v podobě normálových vzdáleností všech vrcholů trojúhelníkové sítě $3 \mathrm{D}$ mesh modelu od referenčního mračna bodů byly vypočteny pomocí funkce Cloud-to-Mesh Distance (C2MD) [10]. Na základě odchylek od referenčního mračna byly vypočteny směrodatné 3D polohové odchylky S3D. Odchylky byly dále testovány dle [9] na výskyt vybočujících (5\% kritická hodnota) a odlehlých (1\% kritická hodnota) hodnot.

Testování shody mezi fotogrammetrickými výsledky z kamery Canon EOS 6D Mark II a kamery Xiaomi Mi $10 \mathrm{~T}$ Pro bylo provedeno na základě testu shody výběrových směrodatných 2D polohových odchylek S2D a směrodatných výškových odchylek $\mathrm{s}_{\mathrm{H}} \mathrm{S}$ využitím F-testu na hladině významnosti $1 \%$.

\section{VÝSLEDKY}

Na Obr. 3 lze vidět výsledné 3D mesh modely kaple. Výsledky analýzy souřadnicových odchylek na kontrolních bodech jsou uvedeny v Tab. 5. Hodnoty v tabulce reprezentují přesnost výsledných modelů v diskrétních, dobře identifikovatelných bodech na objektu. U mobilního telefonu Xiaomi byla identifikována 1 odlehlá a 2 vybočující hodnoty výškových odchylek. U kamery Canon byla identifikována 1 vybočující hodnota $2 \mathrm{D}$ polohové odchylky a 1 odlehlá hodnota výškové odchylky.

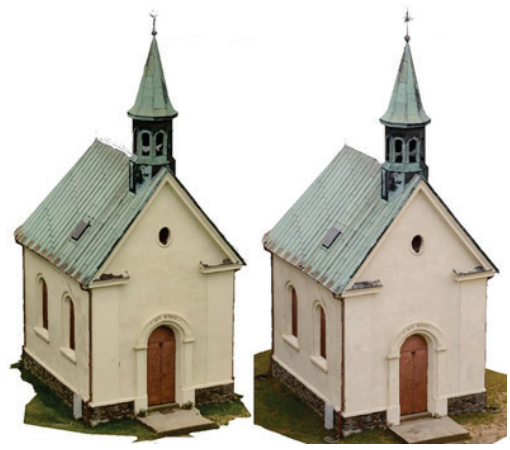

Obr. 3 Výsledné 3D mesh modely (vlevo Xiaomi, vpravo Canon). 
Tab. 5 Výsledky analýzy 2D polohových a výškových odchylek na kontrolních bodech.

\begin{tabular}{ccc}
\hline Parametr & Xiaomi Mi 10T Pro & Canon EOS 6D Mark II \\
\hline Počet kontrolních bodů & 30 & 25 \\
Směrodatná 2D polohová odchylka S2D & $6,7 \mathrm{~mm}$ & $7,5 \mathrm{~mm}$ \\
Směrodatná výšková odchylka SH & $5,1 \mathrm{~mm}$ & $5,2 \mathrm{~mm}$ \\
Směrodatná 3D polohová odchylka S3D & $8,4 \mathrm{~mm}$ & $9,1 \mathrm{~mm}$ \\
\hline
\end{tabular}

Test shody směrodatných 2D polohových odchylek S2D a směrodatných výškových odchylek SH pomocí F-testu na hladině významnosti $1 \%$ na kontrolních bodech u obou kamer prokázal statisticky srovnatelnou přesnost fotogrammetrických výsledků z obou kamer na dobře signalizovaných kontrolních bodech.

Grafické znázornění odchylek mesh modelů z obou kamer od referenčního mračnu bodů z pozemního laserového skenování znázorňuje Obr. 4.
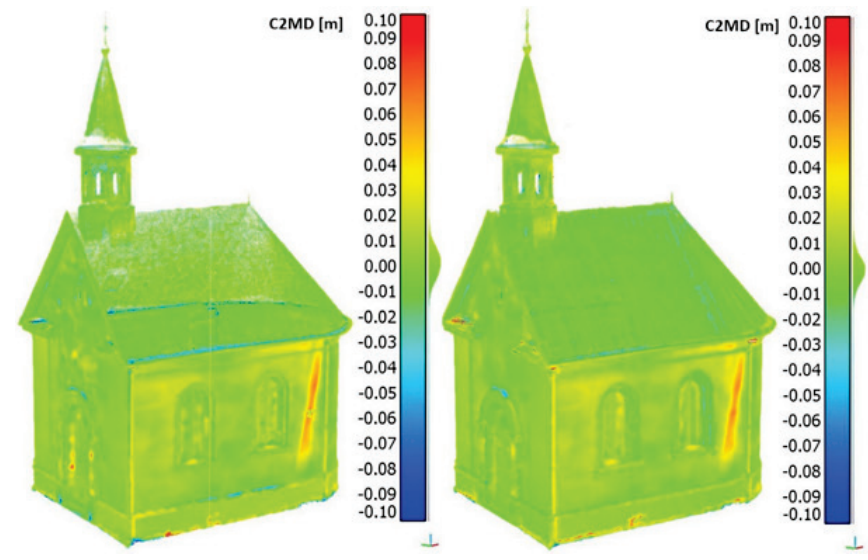

Obr. 4 Grafické znázornění analýzy odchylek mesh modelů od referenčního mračna bodů.

Přesnost 3D mesh modelů v podobě směrodatných odchylek vypočtených na základě odchylek mesh modelů od referenčního mračna bodů a výsledky testování těchto odchylek na výskyt vybočujících a odlehlých hodnot jsou uvedeny v Tab. 6. Test shody na hladině významnosti $1 \%$ směrodatných 3D polohových odchylek S3D vypočtených na základě porovnání mesh modelů s referenčním mračnem prokázal statisticky srovnatelnou přesnost fotogrammetrických výsledků z obou kamer.

Tab. 6 Výsledky testování přesnosti výsledných mesh modelů.

\begin{tabular}{ccc}
\hline Prvek & Xiaomi Mi 10T Pro & Canon EOS 6D Mark II \\
\hline Směrodatná 3D polohová odchylka S3D & $13,5 \mathrm{~mm}$ & $15,9 \mathrm{~mm}$ \\
Zastoupení vybočujících hodnot & $2,3 \%$ & $1,1 \%$ \\
Zastoupení odlehlých hodnot & $4,1 \%$ & $2,1 \%$ \\
\hline
\end{tabular}

\section{ZÁVĚR}

Na základě snímků z kamery mobilního telefonu Xiaomi Mi 10T Pro a digitální zrcadlové kamery Canon EOS 6D Mark II byly vytvořeny 3D mesh modely kaple Panny Marie Pomocnice v Brně-Líšni.

Při zjednodušeném testu 2D polohových odchylek a výškových odchylek na kontrolních bodech na př́itomnost vybočujících a odlehlých hodnot byla u mobilního telefonu Xiaomi identifikována 1 odlehlá a 2 vybočující hodnoty výškových odchylek. U digitální zrcadlové kamery Canon byla identifikována 1 vybočující hodnota 2D polohové odchylky a 1 odlehlá hodnota výškové odchylky.

$\mathrm{Na}$ základě testu shody směrodatných $2 \mathrm{D}$ polohových odchylek a směrodatných výškových odchylek na kontrolních bodech byla prokázána statisticky srovnatelná přesnost mezi fotogrammetrickými výsledky ze snímkování oběma kamerami v místech dobře signalizovaných kontrolních bodů (místech, kde lze očekávat nejvyšší přesnost fotogrammetrických výsledků) při stejné snímkovací vzdálenosti. 
Přesnost 3D mesh modelů, charakterizovaná směrodatnými 3D polohovými odchylkami, vypočtená na základě porovnání mesh modelů s referenčním mračnem odpovídá hodnotám $\mathrm{s}_{3 \mathrm{D}}=13,5 \mathrm{~mm}$ (Xiaomi Mi 10T Pro) a $\mathrm{S}_{3 \mathrm{D}}=15,9 \mathrm{~mm}$ (Canon EOS 6D Mark II). Přesnost mesh modelů vypočtená na základě porovnání s referenčním mračnem je přibližně $1,5 \times$ horší, než přesnost vypočtená na základě odchylek na kontrolních bodech $\left(\mathrm{s}_{3 \mathrm{D}}=8,4 \mathrm{~mm}\right.$ u Xiaomi Mi 10T Pro a S3D $=9,1 \mathrm{~m}$ m u Canon EOS 6D Mark II). Zatímco s3D vypočtené na základě porovnání s referenčním mračnem charakterizují přesnost celého 3D mesh modelu, $\mathrm{S}_{3}$ D vypočtené na základě odchylek na kontrolních bodech charakterizují přesnost 3D mesh modelů v diskrétních, dobře identifikovatelných bodech. Při testu odchylek mesh modelů a referenčního mračna na výskyt vybočujících a odlehlých hodnot bylo u mobilního telefonu Xiaomi identifikováno 2,3 \% vybočujících a 4,1 \% odlehlých hodnot, u digitální zrcadlové kamery Canon pouze $1,1 \%$ vybočujících a 2,1\% odlehlých hodnot. Test shody směrodatných 3D polohových odchylek obou modelů prokázal statisticky srovnatelnou přesnost obou modelů.

Mesh model vytvořený na základě snímků z mobilního telefonu Xiaomi Mi 10T Pro (rozlišení snímků 108Mpx) má dvojnásobné zastoupení vybočujících a odlehlých hodnot v porovnání s modelem ze snímkování digitální zrcadlovou kamerou Canon (26,2 MPx). Z důvodu méně kvalitní optiky kamery Xiaomi Mi 10T Pro tedy nelze, při zachování stejných parametrů snímkování, dosáhnout stejně kvalitních fotogrammetrických výsledků v porovnání s profesionálními kamerami. Přes uvedené nedostatky, a zejména při uvážení pětinové pořizovací ceny ve srovnání s kamerou Canon, se nabízí mobilní telefon Xiomi Mi 10T Pro jako zajímavá alternativa k profesionálním kamerám. Při zvolení vhodných parametrů snímkování lze i pomocí takovéto nízkonákladové kamery dosáhnout kvalitních fotogrammetrických výsledků.

\section{Poděkování}

Článek vznikl v rámci řešení projektu Specifického výzkumu VUT v Brně FAST-S-21-7484 Efektivita využití low-cost kamer v aplikacích blízké fotogrammetrie.

\section{Použité zdroje}

[1] Yilmazturk F, Gurbak AE. Geometric Evaluation of Mobile-Phone Camera Images for 3D Information. International Journal of Optics [Internet]. 2019Sep.30;2019:1-10. Available from: https:/www.hindawi.com/journals/ijo/2019/8561380/

[2] Ebrahim M. Using Mobile Phone Digital Cameras in Digital Close Range Photogrammetry. The Photogrammetric Journal of Finland. 2004;19(1).

[3] Gruen A, Akca D. Monile Phoftogrammetry. Dreiländertagung SGPBF, DGPF und OVG. 2007;19:441451.

[4] Mi 10T | 5G Specs [Internet]. Mi Global Home. [cited 2021Nov.5]. Available from: https:/www.mi.com/global/mi-10t/specs/

[5] Canon EOS 6D Mark II tělo [Internet]. Megapixel. [cited 2021Nov.5]. Available from: https://www.megapixel.cz/canon-eos-6d-mark-ii-telo\#section-parameters

[6] Canon EF 24 mm f/1,4 L II USM [Internet]. Megapixel. [cited 2021Nov.5]. Available from: https://www.megapixel.cz/canon-ef-24-mm-f-1-4-1-ii-usm\#section-parameters

[7] Technical Specification Sheet for the Focus3D X 30/130/330 and X 130/330 HDR [Internet]. Faro. [cited 2021Nov.5]. Available from:

https://knowledge.faro.com/Hardware/3D_Scanners/Focus/Technical_Specification_Sheet_for_the_F ocus3D_X_30-130-330_and_X_130-330_HDR

[8] Trimble S8 Total Station Datasheet [Internet]. [cited 2021Dec.17]. Available from: http://www.kmcgeo.com/Datasheets/S8_DS_2011.pdf

[9] Kalvoda P, Nosek J, Kuruc M, Volarik T, Kalvodova P. Accuracy Evaluation and Comparison of Mobile Laser Scanning and Mobile Photogrammetry Data. IOP Conference Series: Earth and Environmental Science [Internet]. 2020Dec.1;609. Available from: https://iopscience.iop.org/article/10.1088/1755$1315 / 609 / 1 / 012091$

[10] Cloud-to-Mesh Distance [Internet]. CloudCompareWiki. [cited 2021Dec.22]. Available from: https://www.cloudcompare.org/doc/wiki/index.php?title=Cloud-to-Mesh_Distance 